Київський університет імені Бориса Грінченка

GPOGIT⿱乛龰 ИГДРНН̆

ТА ЙОГО ДОБА:

ТИСЯЧОЛІТНІЙ ДОСВІД

УКРАЇНСЬКОГО ДЕРЖАВОТВОРЕННЯ

Київ - 2019 
Вченою радою Київського університету імені Бориса Грінченка

$$
\text { (протокол № від } 2019 \text { р.) }
$$

Керівник проекту, голова редакційної колегї̈

Огнв'юк В. О., ректор Київського університету імені Бориса Грінченка, доктор філософських наук, професор, академік НАПН України

\section{Р ед а кц і йн а колегі я:}

Александрова О. С., Андрєєв В. М., Додонов Р. О., Руснак I. Є., Салата О. О.

Р ец ен з ен т и:

Колесник В. Ф., завідувач кафедри давньої та нової історії України Історичного факультету Київського національного університету імені Тараса Шевченка, доктор історичних наук, професор, член-кореспондент НАН України;

Тельвак B. B., професор кафедри давньої історії України та спеціальних історичних дисциплін Дрогобицького державного педагогічного університету імені Івана Франка, доктор історичних наук.

Ярослав Мудрий та його доба: тисячолітній досвід українського дерЯ76 жавотворення / редкол.: Огнев’юк В. О., Александрова О. С., Андрєєв В. М., Додонов Р. О. - Київ, 2019. - 284 с.

ISBN 978-617-658-073-7

Книга присвячена особі та епосі одного з найвидатніших державних діячів української історії - великому князю Ярославу I Володимировичу, якого нащадки прозвали Мудрим. 2019 року виповнилася тисяча років від початку його князювання в Києві. Сьогодні в незалежній Україні ми відзначаємо цю подію, адже внаслідок тривалої державотворчої діяльності Ярослава Русь перетворилася на одну з найпотужніших країн середньовічної Європи.

Увазі читача пропонуємо розвідки, у яких автори в популярній формі висвітлюють добу й постать Ярослава Мудрого, різноманітні аспекти діяльності великого київського князя та їі значення в історії української державності й культури.

Для всіх, хто цікавиться історією України. 


\section{Передмова}

K нига присвячена особі та епосі одного 3 найвидатніших державних діячів нашої історії - великому князю Ярославу Володимировичу, якого нащадки прозвали Мудрим. 2019 р. виповнилася тисяча років від початку його князювання у Києві. Сьогодні в незалежній Україні ми відзначаємо цю подію, адже внаслідок тривалої державотворчої діяльності Ярослава Русь перетворилася на одну з найпотужніших країн середньовічної Європи.

Особливістю української історії $є$ іiї дискретний характер - етапи державності межували $з$ вельми тривалими періодами бездержавного існування. Утім, витоки українського державотворення починаються у IX ст., 3 тих самих часів, коли на широких просторах Східної Європи внаслідок розвитку слов'янських племен, а також під впливами їніх сусідів почала складатись одна $з$ найбільших держав середньовічної Європи - Русь, Руська земля. Вона стала історично важливою контактною зоною між Арабським Сходом, Західною Європою, Візантією і Скандинавією. Це зумовило іiі швидке входження в загальноєвропейську культурну спільність. Русі належить особливе місце серед країн Східної Європи, аналогічне тому, яке посідала імперія Карла Великого в історії Західної Європи ${ }^{1}$.

Про могутню східнослов'янську державу писали у своїх творах ранньосередньовічні арабські та візантійські автори, західноєвропейські хроністи, також про неї згадують скандинавські саги і французький епос ${ }^{2}$.

В історіографічній традиції XIX-XX ст., оскільки первісним територіально-полі- тичним центром Русі була Середня Наддніпрянщина зі столицею у Києві, утвердилася назва Київська Русь.

У першій половині IX ст. Русь була доволі аморфним та крихким державним об'єднанням, яке науковці справедливо називають «дружинною державою». На зламі $\mathrm{IX}-\mathrm{X}$ ст. територія цього політичного утворення обмежувалася Києвом і прилеглими до нього територіями подніпровських полян. Невдовзі місцева родова князівська влада згасла, і іï на початку 80-х років IX ст. заступила династія вихідців із Скандинавії - Рюриковичі ${ }^{3}$.

Наприкінці X - першій половині XI ст. Київська Русь поступово перетворюється на потужну ранньосередньовічну державу, що було наслідком діяльності кількох поколінь київських князів і насамперед Володимира (980-1015) та Ярослава (10191054). Але саме за правління Ярослава Володимировича Київська держава стала поруч 3 провідними країнами Європи. Саме тоді Русь досягла найвищого за всю свою історію міжнародного значення. Тісні стосунки підтримувалися з Польщею, Чехією, Угорщиною, Болгарією, Грузією, Вірменією, Волзькою Булгарією, Францією, Англією, Данією, Швецією, Норвегією та Візантією. Основними пріоритетами зовнішньої політики були укріплення кордонів на сході, побудова оборонних ліній проти кочовиків та відновлення західних кордонів ${ }^{4}$.

Ярослав, захищаючи країну від нападів степовиків, пересунув оборонні лінії на кілька десятків кілометрів у бік степу. Так було побудовано міста на річках Рось та Трубіж (Корсунь, Канів, Переяслав), укріплено

\footnotetext{
${ }^{1}$ Історія української культури: в 5 т. К., 2001. Т. 1. С. 675.

${ }^{2}$ Там само.

${ }^{3}$ Ричка В. М. Києво-руська спадщина. Політична система для України: історичний досвід і виклики сучасності. К., 2008. С. 16-17.

${ }^{4}$ Давня історія України: в 3 т. К. 2000. Т. 3. С. 292.
} 
посульську фортифікаційну лінію (Лубни, Лукомль, Воїнь). Усе це зміцнило границі та надало можливість під час загрози з боку кочовиків краще підготувати столицю до оборони. 1036 р. відбувся останній великий набіг печенігів на Русь, коли вони обложили Київ. Князь з допомогою варягів та новгородців ущент розбив ворога, значна частина нападників загинула під час битви й утечі. Більше печеніги не загрожували Русі.

Важливою складовою зовнішньої політики Ярослава був північний та західний напрями. Тогочасні київські князі й верхівка руського суспільства вважали себе частиною норманського світу, адже були пов'язані з ним походженням, родинними, культурними та військовими зв'язками. До Ярославового правління озброєні загони варягів з'являлися на Русі як запрошені на службу, так і самостійно; вони відігравали помітну роль у різних сферах місцевого життя. Натомість Ярослав змінив цю традицію і почав сам активно втручатися у внутрішні справи норманських королівств.

Руський князь був популярним героєм скандинавських саг. Він постає як активний i впливовий правитель. Під час міжусобної боротьби за норвезький трон Ярослав прихистив Олафа II Норвезького та допоміг йому в поверненні влади, а коли той загинув опікувався його сином Магнусом (король Норвегії (1035-1047) і Данії (1042-1047) Магнус Добрий). Майбутній король Норвегії (1046-1066) Гаральд III Суворий після смерті свого старшого брат Олафа II також знайшов порятунок на Русі. 1031 р. він із загоном варягів став на службу до Ярослава. Згодом Гаральд одружився на дочці князя Єлизаветі Ярославні.

У Києві знаходили притулок і політичні емігранти з інших країн Європи. 3 Англіїанглосаксонський принц Едуард Вигнанець (Етелінг), з Угорщини - майбутній король Андраш і Білий (Католик) (правив у 10471060 рр.). За Андраша Ярослав видав свою дочку Анастасію.

Найбільш вдалим був польський напрям політики Ярослава. Руському князю вдалося збільшити державні території (були відвойовані Белз і Червенські землі) та посадити на польський престол свого зятя Казимира й допомогти йому перемогти ворогів. Також у результаті походів на литовські та ятвязькі землі Ярослав укріпив позиції Русі на Балтійському узбережжі. Надалі відносини 3 європейськими країнами були цілком дружніми.

Водночас Ярослав Володимирович спробував змінити баланс сил й у стосунках із Візантією, яка на той час залишалася однією з наймогутніших імперій світу. Утім, військові дії руських дружин проти ромеїв були невдалими і війна 1143 р. для Русі закінчилася поразкою. Однак завдяки дипломатичним талантам великого князя, Києву вдалося встановити вигідні торгові відносини з Константинополем. Крім того, Ярослав одружив свого сина Всеволода 3 дочкою візантійського імператора Костянтина IX Мономаха Марією.

Одноосібне правління Ярослава позначилося припиненням внутрішніх міжусобних конфліктів. Це був період спокою на Русі - практично всі війни велися за пї межами і там, де це було вигідно державі.

Визначних успіхів на цей час досяг розвиток культури. Сам київський князь був великим книголюбом та прихильником освіти. При митрополичій кафедрі та великокнязівському дворі переписувалися та перекладалися книги, збиралися церковні й історичні твори. Тут, а також при монастирях та храмах, князівських дворах засновувались бібліотеки й школи ${ }^{1}$.

У головному храмі Русі (Софійському соборі) Ярослав влаштував першу книгозбірню, у якій зберігалося до дев'ятисот томів рукописних книг. Серед них були не тільки богослужбові, а й для повсякденного повчального читання. Поява книжкової писемності була вищим виявом писемної культури. Найдавніші руські книги, що збереглися до нашого часу, - Реймське та Остромирове Євангелія (обидві датуються серединою XI ст.). Перше колись належало дочці Ярослава - Анні Ярославні, яка, взявши шлюб

${ }^{1}$ Давня історія України: в 3 т. К. 2000. Т. 3. С. 290-291. 
3 королем Генріхом I Капетингом, привезла iï до Франції. Друга - виконана на замовлення новгородського посадника Остромира й призначалася для Софійського собору в Новгороді ${ }^{1}$.

Володимир після релігійної реформи 988 р., коли виникла потреба в навчанні та вихованні грамотних людей, запровадив державні школи для забезпечення церкви кліром. За Ярослава ж на Русі почали відкриватися світські школи. Це привело до появи прошарку писемного й у той же час непов'язаного із церквою населення, що було надзвичайною рідкістю для середньовіччя ${ }^{2}$.

Чимало зусиль Ярослав прикладав до перетворення Києва на культурний та політичний центр тогочасного цивілізованого світу, який би суперничав із самим Константинополем. На цій ниві він досяг чималих успіхів. Великий князь, наслідуючи столицю Візантії, намагався надати Києву не меншої величі. Розпочалося будівництво «Града великого». Так у столиці було побудовано Золоті ворота, Софійський собор, Георгіївський та Ірининський монастирі й інші кам'яні церкви. Активно велося кам'яне будівництво, стіни храмів розписувалися фресками, бані золотилися. Київ було оповито новою лінією могутніх укріплень. Територія «Верхнього міста» в цей час збільшилася майже в десять разів $^{3}$. Столиця швидко розросталася. Місто утверджується як політичний і духовний центр Русі. Ярославу вдалося підняти ідеологічний статус Києва до рівня Константинополя.

Великий князь київський прагнув надати своїй владі царського ореолу. Про це свідчить низка фактів. Так, на графіті Софійського собору Ярослава названо царем. На карбованих князем срібних монетах разом із ликом Ярослава міститься зображення св. Георгія (його небесний покровитель), якого у Візантії вшановували і як великомученика, і як святого воїна. Св. Георгій був покровителем візантійського імператора та його війська. Ярослав, перенісши на свої срібники й печатки образ св. Георгія, задекларував свою рівність із візантійським імператором. Імовірно, що цій же меті було підпорядковано встановлення в центральному нефі Софії Київської шиферної плити з вирізьбленим на ній за візантійським зразком зображенням геральдичного орла, який мав символізувати міць і силу влади Ярослава ${ }^{4}$.

Природним кроком київського князя, що прагнув рівності з Константинополем, було бажання зробити руську церкву незалежною від Візантії. Раніше київського митрополита призначав константинопольський патріарх, але на соборі 1051 р. руські єпископи самі обрали собі предстоятеля близького до Ярослава, відомого вітчизняного церковного діяча, письменника та філософа Іларіона. Цим актом Руська держава заявляла про фактичну незалежність Руської митрополії від Константинопольського патріархату. Цей надзвичайно важливий крок у політичному та ідеологічному житті Русі став можливим завдяки великому авторитету Ярослава й Іларіона ${ }^{5}$.

Одним із найважливіших внесків Ярослава у розвиток державності на Русі було укладання першого зводу законів «Правди Ярослава» (імовірно - 1016 р.), який згодом нащадки князя розвили у юридичний кодекс «Руську правду». Саме цей документ поклав початок писаного права на Русі. До Ярослава правосуддя здійснювалося згідно $з$ нормами звичаєвого права, що історично склалися в різних регіонах Русі й мали власні особливості. Важливою складовою тогочасного встановлення справедливості та відплатою за злочини була кровна помста, яка послаблювала суспільство. «Правда» ж обмежила кровну помсту

\footnotetext{
${ }^{1}$ Висоцький С. О. Київська Русь. Писемність. Освіта. Історія української культури: в 5 т. К., 2001. Т. 1. С. 717.

2 Там само. С. 724-726.

${ }^{3}$ Асеєв Ю. С., Харламов В. О. Архітектура дерев’яна та кам’яна. Історія української культури: в 5 т. К., 2001. T. 1. C. 844.

${ }^{4}$ Ричка В. М. Києво-руська спадщина... С. 35.

${ }^{5}$ Давня історія України. Т. 3. С. 290-291.
} 
й згодом її було скасовано синами Ярослава. Нове законодавство гарантувало особисту безпеку людини та недоторканність власності. Встановлювалися фіксовані, незмінні покарання, переважно грошові штрафи, за певний тип правопорушення або злочину. Піддані мали право на самозахист, але їм не дозволялося вбивати нападника без суду, чинити самосуд. Надзвичайно важливим був і закон про наслідування княжої влади, який мав припинити чвари й ворожнечу, що неминуче виникали між дітьми та родичами після смерті правителя.

«Правда Ярослава» регламентувала норми правової поведінки на всій території Руської держави. Імовірно, що саме тоді князівська влада вперше набуває характеру урядової і князь з «начальника дружини» перевтілюється на представника «земської влади». Отже, кодифікаційна діяльність
Ярослава була важливою віхою у формуванні політичного суспільства на Русі. «Руська правда» зруйнувала архаїчні родоплемінні правові традиції, зрівнявши в правах пересічне населення 3 представниками князівської дружини. Єдиний закон, гарантом якого став київський князь, відповідав єдиновладній формі його правління ${ }^{1}$.

Таким чином, за доби Ярослава Київська Русь стала могутньою європейською державою, кордони якої простягалися від Балтики й Північно-Льодовитого океану до Чорного моря і від Карпат до Волго-Окського межиріччя.

Отже, увазі читача пропонуються нариси, у яких автори висвітлюють епоху Ярослава Мудрого, різноманітні аспекти діяльності великого київського князя та іï значення для історії української державності й культури.

${ }^{1}$ Ричка В. М. Києво-руська спадщина... С. 34-35. 


\section{Післямова}

G поха Ярослава Мудрого попри наявні контроверсійні оцінки характеризується як доба найвищого піднесення Київської Русі, розквіту православ'я й духовності у східних слов'ян. Незважаючи на тривалий і суперечливий шлях до влади, який пройшов Ярослав Володимирович, роки його правління називають «золотим віком» Київської Русі. Вдало комбінуючи дипломатію та військову силу, він перетворив Русь на потужну європейську державу, з якою мали рахуватися і в Константинополі, і в Кракові, і в Парижі.

Історичний вибір, зроблений рівноапостольним князем Володимиром, визначив зміст політики його сина. Невипадково невідомий автор XI ст. порівнював обох державців із землеробами: «...Володимир землю взорав і розм'якшив, рекше Хрещенням просвітив, сей же [Ярослав] насіяв книжними словесами серця вірних людей; а ми пожинаємо, учення приймаючи книжне» ${ }^{1}$ Якщо хрещення Русі, тобто сам цивілізаційний вибір, є безперечним досягненням Володимира Великого, то Ярославу Мудрому випала доля усвідомлення суті цього вибору, адже прийняття християнства від Візантії сформувало той цивілізаційно-світоглядний код, те ціннісне ядро, яке на тисячоліття визначило спосіб життя українського народу. Власне кажучи, саме тут, в епоху Ярослава Мудрого, слід шукати ознаки, які дозволять відповісти на вкрай актуальне сьогодні питання про цивілізаційну ідентичність України.

Адепти «руського міра» або навмисно не помічають принципової розбіжності Київської Русі з тим азійським за своїм походженням цивілізаційним кодом, що сформувався в Московії після монголо-татарської навали, або маскують цей факт, вказуючи на «несамодостатній», «перехідний», «транзитивний» характер України-Русі. Зрештою всі ці концепції ${ }^{2}$ спрямовані на відтворення старої міфологеми «Москва - Третій Рим», носять маніпулятивний характер і виконують функцію ідеологічної легітимації неоімперських претензій сучасної Росії на панування над Україною. Критикуючи їх зміст, авторитетний дослідник локальних цивілізацій Ю. Павленко писав, що «казати про цивілізаційну “транзитність" України абсурдно вже тому, що традиція цивілізаційного розвитку Середнього Придніпров'я, зокрема, Києва, перевищує тисячоліття. I ця традиція $\epsilon$ цілком визначеною, пов'язаною з православною, укоріненою у візантійсько-східнохристиянську цивілізацію Середньовіччя» ${ }^{3}$. Підсилюючи цю тезу, М. I. Михальченко пише навіть про самостійну «регіональну українську цивілізацію» ${ }^{4}$.

Тисячолітня цивілізаційна традиція не вміщується в примітивну схему естафети, яку начебто Київська Русь у вигляді православ'я передає від Візантії до Москви, перетворюючись на периферію (о-країну)

\footnotetext{
${ }^{1}$ Лаврентьевская летопись. Стб. 151 (статья 1037). Полное собрание русских летописей. Т. 1. М., 1997.

2 Див., наприклад, Черниш О. М. Транзитні цивілізації. Практична філософія. 2001. № 1; Дергачов В. Геополітика. К., 2000; Ткаченко В., Реєнт О. Україна на межі цивілізацій (історико-політологічні розвідки). К., 1995; Кремінь В., Табачник Д., Ткаченко В. Україна: альтернатива поступу (критика історичного досвіду). К., 1996; Муза Д. Є. Восточнохристианская цивилизация: социокультурное устроение и идентичность: моногр. Донецк: Вебер, 2009. 475 с.; Панарин А. С. Православная цивилизация в глобальном мире. Алгоритм, 2002. 496 с.

${ }^{3}$ Павленко Ю. Цивілізаційна природа України та глобальні протиріччя сучасного світу. Давньоруське любомудріє: Тексти і контексти. К.: Вид. дім «Києво-Могилянська академія», 2006. С. 358.

${ }^{4}$ Михальченко М. І. Українська регіональна цивілізація. Політичний менеджмент. 2003. № 1. С. 19-28.
} 
великої євразійської цивілізації. Уже фундатор цивілізаційного підходу А. Дж. Тойнбі мав сумніви: слід говорити про монолітний Східнохристиянський світ чи варто розрізняти в ньому дві окремі, споріднені і генетично пов'язані між собою цивілізації Візантійсько-Східнохристиянську та Східнослов'янсько-(Русько)-Православну?

Спеціально досліджуючи цю проблему, Ю. В. Павленко схилявся до другого варіанту ${ }^{1}$. На його думку, Київська Русь, яка водночас була і субцивілізаційною структурою Візантійсько-Східнохристиянського світу, і макроетнічною східнослов'янською спільністю, поза сумнівом, була основою формування і подальшого розвитку Східнослов'янсько-Православної цивілізації. «Остання в межах Російської імперії та (у викривленому, «іконоборчеському» вигляді) СРСР набуває виразних ознак євразійської геополітичної системи. Але слід наголосити, що така система має не власне цивілізаційну, а, так би мовити, квазіцивілізаційну природу, оскільки базувалася не на спільному ідейно-ціннісно-мотиваційному, духовному тлі (що $є$ природним для кожної цивілізаціі), а (як імперія Чингізидів) трималася, перш за все, на військово-політичній структурі. Отже, євразійська спільність, маючи деякі ознаки окремої цивілізації, $є$ квазіцивілізаційним утворенням» ${ }^{2}$.
Оцінюючи значущість тієі чи іншої історичної постаті, необхідно виходити з так званої «презумпції майбутнього». Ярослав Мудрий навіть не підозрював, яке майбутнє чекає на Київську державу. Розкол християнства на католицизм та православ'я, монгольська навала, зруйнування Києва, століття золотоординського панування, захоплення османами Візантії і політичне піднесення Московії - все це відбулося після смерті Ярослава. Було б помилкою покладати на нього відповідальність за ці події. Тому сучасні дискусії щодо цивілізаційної приналежності Київської Русі стосуються Ярослава Мудрого лише в тому сенсі, в якому він уособлював згаданий вище ідейно-ціннісно-мотиваційний код.

Спираючись на цінності материнської щодо Києва Візантійсько-Східнохристиянської цивілізації, Ярослав Мудрий та його книжники в цілому впоралися з історичною місією, що випала на їхню долю, формування відповідних християнському світогляду морально-етичних, політико-правових і духовних засад життя свого народу. Саме це, а зовсім не військова потуга, дає нам змогу констатувати існування відповідного локально-цивілізаційного типу, який попри всі випробування й історичні катаклізми зберігається в ментальності українців вже тисячу років.

Олена Александрова, Віталій Андрєєв, Роман Додонов

\footnotetext{
${ }^{1}$ Павленко Ю. В. Етнічний розвиток Київської Русі. Генеза. 1998. № 1-2 (6-7). С. 88-93.

${ }^{2}$ Павленко Ю. Цивілізаційна природа України та глобальні протиріччя сучасного світу. Давньоруське любомудріє: Тексти і контексти. К.: Вид. дім «Києво-Могилянська академія», 2006. С. 360.
} 


\section{Відомості про авторів}

Александрова Олена, професор Історико-філософського факультету Київського університету імені Бориса Грінченка, доктор філософських наук.

Андрєєв Віталій, професор Київського університету імені Бориса Грінченка, доктор історичних наук.

Бонь Олександр, доцент Київського університету імені Бориса Грінченка кандидат історичних наук.

Борисенко Катерина, доцент Київського університету імені Бориса Грінченка, кандидат філологічних наук.

Гай-Нижник Павло, завідувач відділу історичних студій Науково-дослідного інституту українознавства, доктор історичних наук.

Делорм Філіпn, французький історик, дослідник генеалогії королівських родин. Демиденко Григорій, професор Національного юридичного університету імені Ярослава Мудрого, доктор історичних наук.

Денисенко Володимир, доцент Інституту філології та масових комунікацій Відкритого міжнародного університету розвитку людини «Україна», член Спілки журналістів України, доктор історичних наук.

Додонов Роман, професор Київського університету імені Бориса Грінченка, доктор філософських наук.

Драч Оксана, професор Київського університету імені Бориса Грінченка, доктор історичних наук.

Калакура Ярослав, професор Київського національного університету імені Тараса Шевченка, доктор історичних наук.

Ковальчук Наталія, професор Київського університету імені Бориса Грінченка, доктор філософських наук.

Козлов Роман, доцент Київського університету імені Бориса Грінченка, доктор філологічних наук.

Левітас Фелікс, професор Київського університету імені Бориса Грінченка, доктор історичних наук.

Луняк Євген, доцент Ніжинського державного університету імені Миколи Гоголя, доктор історичних наук.

Огнев'юк Віктор, ректор Київського університету імені Бориса Грінченка, доктор філософських наук, професор, академік НАПН України.

Пиеничний Тapac, заступник декана історичного факультету з наукової роботи та міжнародних зв’язків Київського національного університету імені Тараса Шевченка, кандидат історичних наук.

Ричка Володимир, головний науковий співробітник Інституту історії України НАН України, доктор історичних наук, професор.

Руснак Ірина, професор Київського університету імені Бориса Грінченка, доктор філологічних наук.

Сліпушко Оксана, професор Інституту філології Київського національного університету імені Тараса Шевченка, доктор філологічних наук.

Трухан Олександр, професор Київського університету імені Бориса Грінченка, кандидат педагогічних наук.

Щербак Віталій, професор Київського університету імені Бориса Грінченка, доктор історичних наук. 


\section{MICT}

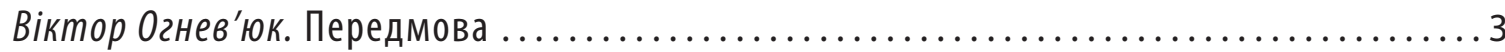

\section{РОЗДІЛ І. ЕПОХА ЯРОСЛАВА МУДРОГО В ІСТОРИЧНОМУ ДИСКУРСІ}

Ярослав Калакура. Витоки українського суспільства

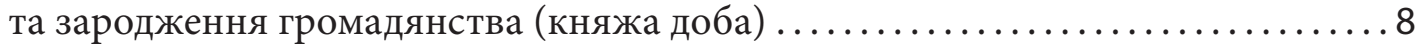

Григорій Демиденко. Біографія Ярослава Мудрого: факти та припущення ...... 17

Володимир Денисенко. Київська держава: духовність, освіта, дипломатія ..... 30

\section{РОЗДІЛ ІІ. РОЗБУДОВА ДЕРЖАВИ ТА ТВОРЕННЯ КУЛЬТУРНОГО ПРОСТОРУ}

Володимир Ричка. REX RUGORUM ............................... 52

Віталій Щербак. На переломі ................................. 77

Григорій Демиденко. Законотворча діяльність Ярослава Мудрого .......... 87

Фелікс Левітас, Олександр Трухан. Князь-воїн: мілітарні традиції

Давньої Русі ............................................... 105

Оксана Сліпушко. Ярослав Мудрий — книжник ..................... 117

Оксана Драч. «Засіяв книжними словами серця вірних»:

освіта й освіченість у Русі ................................... 137

Tарас Пшеничний. Релігія та церква в XI-XII століттях ................ 163

Наталія Ковальчук. Морально-духовні засади державницької політики

Ярослава Мудрого ............................................ 169

\section{РОЗДІЛ ІІІ. КИЇВСЬКА ДЕРЖАВА У ЄВРОПЕЙСЬКІЙ ПОЛІТИЦІ}

\section{ТА ДИПЛОМАТИЧНИХ ВІДНОСИНАХ}

Володимир Ричка. Між Римом і Царгородом ........................ 176

Павло Гай-Нижник. Русько-візантійська війна 1043 р. у контексті

релігійно-міжнародної політики великого князя київського

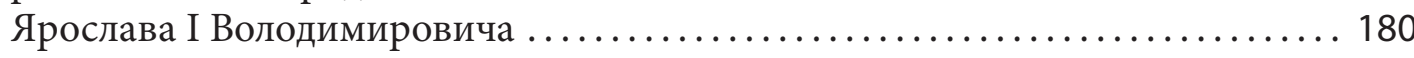

Олександр Бонь. Матримоніальні зв’язки Ярослава

з володарями Європи ........................................ 195

Філіпn Делорм. Красуня з далекого краю ............................ 211

Євген Луняк. Династичний шлюб Анни Ярославни з Генріхом I

та його значення в історії Франції ............................. 216

\section{РОЗДІЛ ІV. ЯРОСЛАВ МУДРИЙ В КУЛЬТУРНО-МИСТЕЦЬКІЙ СПАДЩИНІ}

Катерина Борисенко. Образ Ярослава Мудрого

в «Повъстъ временных лът» ................................. 258

Ірина Руснак. Образ Ярослава Мудрого і його епохи в художніх творах

про Ярославен ......................................... 262

Роман Козлов. Ярослав Мудрий у новій українській літературі:

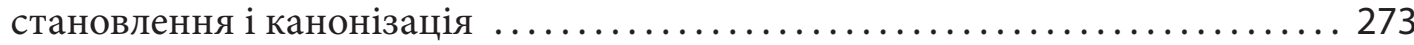

Александрова Олена, Андрєєв Віталій, Додонов Роман. Післямова.................. 280

Відомості про авторів ........................................... 282 


\title{
GPOGITR MГДРНЙ
}

\author{
ТА ЙОГО ДОБА: \\ ТИСЯЧОЛІТНІЙ ДОСВІД \\ УКРАЇНСЬКОГО ДЕРЖАВОТВОРЕННЯ
}

За подані матеріали відповідають автори

Видання підготовлене до друку в НМЦ видавничої діяльності

Київського університету імені Бориса Грінченка

Завідувач НМЦ видавничої діяльності М.М. Прядко

Відповідальна за випуск А.М. Даниленко

Над виданням працювали: Л.В. Потравка, Н.І. Гетьман,

T.В. Нестерова, В.I. Скрябіна

Підписано до друку 00.00.2019 р. Формат 60х84/8.

Ум. друк. арк. 0,00. Обл.-вид. арк. 00,0. Наклад 00 пр. Зам. № 0-00.

Київський університет імені Бориса Грінченка,

вул. Бульварно-Кудрявська, 18/2, м. Київ, 04053.

Свідоцтво суб’єкта видавничої справи ДК № 4013 від 17.03.2011 р.

Попередження! Згідно із Законом України «Про авторське право і суміжні права» жодна частина цього видання не може бути використана чи відтворена на будь-яких носіях, розміщена в мережі Інтернет без письмового дозволу Київського університету імені Бориса Грінченка й авторів. Порушення закону призводить до адміністративної, кримінальної відповідальності. 